\title{
Corporate Profile, Shareholding Position and Firm Profitability: Empirical Results from Pharmaceutical and Chemical Companies of Bangladesh
}

\author{
Md. Amanullah \\ Lecturer of Management, Department of Humanities \\ Khulna University of Engineering \& Technology, Khulna-9203, Bangladesh.
}

\begin{abstract}
The study inspects the effect of corporate profile and shareholding position on firm profitability studying 31 listed pharmaceutical and chemical companies of Bangladesh. The analysis uses five measurements - earning per share (EPS), net profit margin (NPM), return on assets (ROA), return on equity (ROE) and basic earning power (BEP) along with four moderating variables to define firm profitability. The findings demonstrate a positive association of independent directors and firm profitability, while female board-members generate negative results. Board size and the participation of sponsors-promoters produce no meaningful effect. The existing shareholding patterns reveal negative impacts on firm profitability. While public investors and institutes negatively affect the most, the foreign investors and sponsors-directors affect the least. The study suggests to increase the proportion of foreign shareholding and independent directors, decrease the portion of public shareholding and female directors, and opt for the new investment sources to align with positive profitability.
\end{abstract}

Keywords: Profitability, Performance, Corporate profile, Shareholding structure, Corporate governance, Board structure.

DOI: $10.7176 / \mathrm{EJBM} / 13-20-05$

Publication date:October $31^{\text {st }} 2021$

\section{Introduction}

Transparency and corporate governance issues are the burning questions in today's corporate world where the corporations entertain external investment by subordinating ownership. In Bangladesh, transparency and governance have turned to utmost priority especially after the stock market crash in 2010 . There are also a great number of examples of fund mismanagement and fraudulent activities by the promoters, directors and top management. For this reason, investment decision, and consequently the firm performance, inherit a great concern over the corporate profile and ownership structure of a corporation.

Firm profitability, also known as financial performance, greatly depends on top management's visionary move. It is also evident that the failure of a corporation is critically influenced by oblivious functions of the corporate bodies and the subordination of shareholders' interest with management's interest (Abidin et al., 2009). Furthermore, listed public limited companies experience a greater degree of agency problem for isolating management from ownership (Fauzi and Locke, 2012). Besides, the shareholders may not nurture the same opinion to the policies and decisions of the corporate bodies. In this regard, the performance of the firm and its attraction rests on the competence of management to moderate the agency costs and conflict among parties, and to ensure smooth functioning of the organisation.

Corporate profiling including size, gender diversity and independence is also prudent in affecting firm profitability. A more gender-diverse board has a stronger monitoring and controlling capability (Adams and Ferreira, 2009). Fauzi and Locke (2012) observe that the female directors familiarise more skills and new organisational outlook. Moreover, member-size in the corporate body and their independence influence the decision mechanisms of an organisation. Firstly, a large board demonstrates varied skills, knowledge and experience, which are essential to see the big picture and complete judgment of a problem. Hence, a small board may have an inadequacy of knowledge and capabilities. However, unlike the big-sized board, the small board gets the opportunity of prompt decision making and cost advantage. Secondly, conflict of interest and absence of independent members raises the question of competent transparency and governance. The shareholder directors may act for their own accord overlooking the interest of general investors, but the independent directors generally concern for wellbeing of all parties. The presence of independent directors ensures good governance by tradingoff the insider's interests with general investor's interests. Bangladesh Securities and Exchange Commission [BSEC] (2018) makes it obligatory to ensure standard corporate governance that every listed company must appoint at least one-fifth independent directors. Hence, the presence of independent directors may instigate the firm profitability with due consideration of investors' trust, agency conflict and power of inside ownership.

Shareholding position is considered as an important mechanism to ensure corporate governance. For this reason, BSEC has legislated that the sponsors and directors must hold at least 30 percent ownership. Furthermore, the retail investors and institutional investors do not share the same capability to influence the board's functioning 
and decision making process. The shareholding structure also determines the investors' perception and firm outlook in the capital market platform. Hence, the participation of sponsors and directors, instructions, government, foreign individuals and institutions, and retail investors instigates the organisational response either to grab opportunities of greater risk or to walk away by focusing on the traditional path.

\section{Literature Review}

\subsection{Size of Corporate Body}

The corporate body of a firm is responsible for monitoring performance and ensuring internal governance (Erickson et al., 2005). Size of the corporate body is assumed to be a significant factor affecting firm profitability. However, researchers do not prescribe any optimal board size. A large or small board has both merits and demerits for the performance of a firm. Jensen (1986) suggests keeping the board small to ensure objective participation in board activities as large board experiences biases and behavioural difficulties. Black and Kim (2012) conclude that board size negatively affects organisational performance. Furthermore, a smaller board can create value for the stockholder more effectively than a larger board (Kapoor and Goel, 2017).

In contrast, several researchers have recommended for larger board considering its positive relationship with firm profitability (Coles et al., 2008; Klein, 2002; Ehikioya, 2009). A large board conveys more expertise, managerial vision and greater resource accessibility (Chancharat and Chancharat, 2019). Though larger board experiences difficulties in coordination, communication and balancing, it impedes effective decision-making due to lack of diversity (Yermack, 1996). In result, there is a possible trade-off between board multiplicity and coordination (Uadiale, 2010). A large board can ensure higher firm value considering agency theory and resource dependency theory (Fauzi and Locke, 2012). Therefore, studies have concluded a mixed association of board size and organisation profitability. While larger boards convey knowledge diversity and coordination difficulties, smaller boards are away from multiplicity but effective in creating value. From the discussion, the first hypothesis is developed as;

$\mathrm{H}_{1}$ : Size of the corporate body is meaningfully associated with firm profitability

\subsection{Participation of Independent Directors}

Independent directors ensure optimum corporate governance and protect the rights of the shareholder by eliminating conflict of interests and empowering internal monitoring mechanisms (Chancharat and Chancharat, 2019). Board independence can enhance firm performance by controlling the management's self-interest through monitoring systems (Coles et al., 2008). Studies also show that Korean firms' profitability problem primarily arises due to the failure of corporate governance, which can be improved by active participation of independent directors (Baek et al., 2004; Mitton, 2002). In turn, the existence of independent directors is one of the prime drivers to ensure corporate governance. These studies advocate that more outside directors in the corporate bodies are positively affiliated with organisational profitability. Several other studies have concluded similar findings that independent members bring positive outcomes to a firm (Dehaene et al., 2001; Pearce and Zahra, 1992; Hossain et al., 2001).

Active participation of more independent directors can enhance firm profitability by eliminating agency problems. Agency theory implies that the management tends to focus on achieving own interests instead of general investors as people tend to achieve personal goals (Chancharat and Chancharat, 2019). Independent directors can reduce this problem and protect the shareholder's rights by overseeing the management functions (Hu et al., 2010). In this regard, outside directors can contribute to escalate firm profitability by alleviating agency problems.

In contrast, different studies show that independent directors hardly contribute to firm profitability. Researchers concluded with no substantial link between the participation of independent directors and organisation profitability (Haniffa and Hudaib, 2006; Mehran, 1995). In addition, Bhagat and Black (2002) state a negative association of independent directors and firm profitability. Board independence causes negative results due to excessive monitoring and lack of true independence (Haniffa and Hudaib, 2006). Rosenstein (1987) has stated that non-executive directors cannot contribute to firm profitability for little understanding of complex managerial operations and unavailability of dedicated time. The following hypothesis is drawn considering the independent director's role in harmonizing conflict of management-shareholder interest and agency costs.

$\mathrm{H}_{2}$ : Participation of independent directors brings a significant result to firm profitability.

\subsection{Gender Diversity}

The proportion of female members in the corporate bodies is increasing worldwide. Considering the agency theory, female participation in board decision-making encourages balance and diversified board, and reduces the dominance of male directors (Fauzi and Locke, 2012). Female directors may also ensure wide accessibility of resources and a healthier insights of consumer behaviour. Consequently, the resource dependency viewpoint illustrates positive effects of diversified corporate profile on firm profitability (Chancharat and Chancharat, 2019). Understanding the importance of gender diversity, the Stock Exchange of Thailand (SET) has recommended 
making a floor for minimum one female independent director in the management body subject to experience and business knowledge (Chancharat and Chancharat, 2019). Carter et al. (2003) and Bonn (2004) state a positive correlation between female members and organisation value. Besides, the combination of male and female board positively affects organisation profitability and stock value (Jurkus et al., 2008). These studies instigate the following hypothesis;

$\mathrm{H}_{3}$ : Participation of female members in the corporate body is significantly associated with firm profitability

\subsection{Shareholding of Sponsors and Directors and Their Participation in Board}

Sponsor's and promoter's participation in the board may correlate either inversely or positively with firm profitability. Sponsors and promoters can reduce agency conflict and bring positive results for a firm to secure their return on investment (Abidin et al., 2009). A higher degree of managerial ownership may align managershareholder's interests more effectively (Jensen and Meckling, 1976). However, Abidin et al. (2009) conclude an insignificant effect of promoter's ownership on firm's profitability in Malaysian firms. In addition, it may also lead to negative corporate performance if the promoters gain excessive power and start to neglect the interest of general investors (Morck et al., 1988).

Researchers express a mixed effect of sponsor's and director's shareholding on firm performance depending on their motives and willingness. The family-based firms generally experience a positive outcome as the family members tend to reduce agency costs through rigorous monitoring (Panyasrivanit, 2005). However, opposite findings are prescribed for the family-based firms considering the extensive concentration of family member's interests instead of shareholder's general interests (Uadiale, 2010). In addition, McConnell and Servaes (1990) state its noteworthy positive outcome on firm profitability, while Demsetz (1983) expresses negative findings due to increased power of inside ownership.

The mixed findings instigate two theoretical frameworks: alignment effect and entrenchment effect. The alignment effect illustrates the sponsor's and director's motive toward firm value maximisation, while the entrenchment effect prescribes focusing on their self-interests that negatively affect firm value (Kumar and Singh, 2013). A Study explains that firm's net worth increases with the rise of inside shareholding up to 5 percent and starts to decrease when the proportion reached to 25 percent, and again increases slightly with increases in ownership ratio (Morck et al., 1988). Consequently, sponsor's and director's shareholding may significantly affect the organisation's profitability depending on their role to maximise shareholder interest. From the above description, the following hypotheses can be drawn;

$\mathrm{H}_{4}$ : There is a significant impact of sponsor's and/or promoter's participation in the board on firm profitability.

$\mathrm{H}_{5}$ : A significant relationship exists between sponsor and/or director's shareholding and firm profitability.

\subsection{Institutional shareholding}

Institutions are considered quality investors of the capital market. Generally, institutions, also denoted as blockholder, hold a large portion of ownership of a respective firm. The common shareholders have the voting rights to elect their representatives in the corporate body. In turn, the large investors or blockholders like institution can alter the board of directors (BoDs) or may pressurise the board to opt for certain decisions. Furthermore, the institutional shareholder, upon holding a notable portion of share capital, can participate in the board as nominee director. The nominee director secures the same decision making authority as other members of the board. Cho and Kim (2007) state that the large shareholders exercise noteworthy influence in decision making as top management greatly depends on them.

Institutional shareholders' influence on firm profitability depends on their motive, dedication and power over inside ownership. While Hartzella and Starks (2003) find its positive relationship with firm performance, Thomsen and Pedersen (2000) state a bell-shaped relationship. Furthermore, large shareholders reduce retrenchment effect by introducing better monitoring systems (Hossain et al., 2001). On the contrary, Singh and Davidson (2003) conclude that blockholder's participation does not help to diminish agency costs. Therefore, it is argued that the firm's profitability may suffer if institutions or large investors hold power beyond a specified level (Cho and Kim, 2007). In light of the institutional shareholder's interest in return on investment and related research, the following hypothesis is developed;

$\mathrm{H}_{6}$ : Institutional shareholding significantly affects the firm profitability.

\subsection{Shareholding of Foreign Investors}

Participation of foreign investors can transmit industry experience and drive confidence of domestic investors. Douma et al. (2006) prescribe that foreign investors generally invest in the organisations aligned with their core business. Sequentially, the firms may have the opportunity to access the global technical industry-expertise to bring positive firm profitability by integrating their business strategy to global experience. Their participation also 
instigates heterogeneity and knowledge diversity, which may enhance firm proficiency considering resource dependency theory (Douma et al., 2006). Chibber and Majumdar (1999) state that the ratio of foreign ownership is positively correlated with resource and technology transfer. Capability building, wider resource accessibility, and knowledge and technology transfer create relative advantage for a domestic firm to bring greater firm profitability (Sarkar and Sarkar, 2000). Based on these conclusions, the following hypothesis is developed; $\mathrm{H}_{7}$ : Foreign investor's shareholding is significantly linked to firm profitability.

\subsection{Public Shareholding}

The general investors hold a significant proportion of shares in Bangladesh. However, studies suggest that their impulsive behaviour in investment decisions negatively affects equity price at a great extent (Baker and Wurgler, 2006). In turn, it negatively affects firm image and leads to decrease in firm value. The reflection is evident in different listed companies of Bangladesh that security price is quite attractive even though the firms incur losses and prescribe no dividend in the previous year(s), while stock price of several firms with net profit and lucrative dividend has gone below the face value. In addition, the general investors have the rights to elect directors, and to validate or nullify board's decision within legal frameworks in the general meetings. Hence, the public shareholders may have an influence on firm's investment decisions, dividend policy, business expansion plan, capital raising and so on resolutions that can affect firm profitability. From the description, the following hypothesis is developed;

$\mathrm{H}_{8}$ : Public shareholding and firm profitability are significantly related.

\section{Research Methodology}

\subsection{Data}

The study is conducted on 31 listed pharmaceutical and chemical companies listed at any time over the specified period in the sector of the stock exchanges of Bangladesh. However, a company listed under the sector has been excluded from consideration due to the unavailability of accounting data of the corresponding period. Research data are collected from annual reports of the selected firms and Dhaka Stock Exchange Limited (DSE) data archive.

The analysis is based on five years data from the financial year (FY) 2015 to 2020 of the selected companies. The five-year's average data are analysed using SPSS for establishing relationships among variables by means of different statistical tools including descriptive statistics, correlation and Ordinary Least Square (OLS) regression.

\subsection{Dependent variables}

The study uses four financial ratios namely NPM, BEP, ROA and ROE to measure the organisation's profitability (Brigham and Houston, 2012). EPS is also considered to measure profitability.

\subsection{Independent variables}

Four independent variables - size of corporate body (TDR), participation of independent directors (INDR), participation of sponsors and/or promoters in the corporate body (SDR), and female directors in the body (FDR) are measured to institute the affiliation of corporate profile and firm profitability. Other four independent variables- sponsor's and/or director's ownership (SDR), institutional investor's ownership (INST), foreign investor's ownership (FOR), and general investor's ownership (PUB) — are used to institute the association of shareholding position and firm profitability. However, the study excluded the ownership position of the government of Bangladesh due to holding ownership of single company.

\subsection{Control variables}

Control variables produce a better relationship between experimental and target variables by reducing the problems of endogeneity (Kumar and Singh, 2013). The study considers four demographic features-firm size (SIZE), years in business operations (AGE), sales growth (GROW) and financial leverage (LEV) — as control variables to moderate distortions in analysis of variables. 


\subsection{Variables measurement}

Table 3: Measurement of variables

\begin{tabular}{|c|c|c|}
\hline Variables & Definition & Existing studies \\
\hline EPS & Total earnings divided by total outstanding shares & Lim and Rokhim (2020); Nahar (2004) \\
\hline NPM & $\begin{array}{l}\text { Net income for common stockholder divided by } \\
\text { sales }\end{array}$ & Arora and Sharma (2015); Nahar (2004) \\
\hline ROA & $\begin{array}{l}\text { Net profit available for common stockholder } \\
\text { divided by total assets }\end{array}$ & $\begin{array}{l}\text { Adams and Santos (2006); Maury (2006); } \\
\text { Nahar (2004) }\end{array}$ \\
\hline $\mathrm{ROE}$ & $\begin{array}{l}\text { Net profit available for common stockholder } \\
\text { divided by number of common equity }\end{array}$ & $\begin{array}{l}\text { Arora and Sharma (2015); Hamid et al. } \\
\text { (2015); Earle et al. (2005); Nahar (2004) }\end{array}$ \\
\hline BEP & $\begin{array}{l}\text { Earnings before interest and taxes divided by } \\
\text { total assets }\end{array}$ & $\begin{array}{l}\text { Fich and Shivdasani (2006); Boubraki et al. } \\
(2005)\end{array}$ \\
\hline SIZE & Natural logarithm of total assets & $\begin{array}{l}\text { Farhan et al. (2020); Hamid et al. (2015); } \\
\text { Kumar and Singh (2013) }\end{array}$ \\
\hline AGE & $\begin{array}{l}\text { Number of years in operation (from } \\
\text { establishment to 2020; rounded to next unit) }\end{array}$ & $\begin{array}{l}\text { Farhan et al. (2020); Afrifa (2016); Kumar } \\
\text { and Singh (2013) }\end{array}$ \\
\hline GROW & $\begin{array}{l}\text { Sales growth over the year: Existing FY's sales } \\
\text { subtracted by previous FY's sales and divided by } \\
\text { previous FY's sales }\end{array}$ & $\begin{array}{l}\text { Farhan et al. (2020); Hamid et al. (2015); } \\
\text { Kumar and Singh (2013) }\end{array}$ \\
\hline LEV & $\begin{array}{l}\text { Financial leverage: Total liabilities divided by } \\
\text { shareholder's equity divided }\end{array}$ & Farhan et al. (2020); Afrifa (2016) \\
\hline
\end{tabular}

Note: NPM, ROA, ROE, BEP and GROW are calculated in percentage

3.6 Techniques of Analysis

The study findings are concluded interpreting the results of OLS regression analysed based on the following models;

i. Corporate Profile and Firm Profitability

$\mathrm{EPS}=\beta_{0}+\beta_{1}(\mathrm{INDR})+\beta_{2}(\mathrm{SDR})+\beta_{3}(\mathrm{TDR})+\beta_{4}(\mathrm{FDR})+\beta_{5}(\mathrm{SIZE})+\beta_{6}(\mathrm{AGE})+\beta_{7}(\mathrm{GROW})+\beta_{8}(\mathrm{LEV})+\varepsilon$

$\mathrm{NPM}=\beta_{0}+\beta_{1}(\mathrm{INDR})+\beta_{2}(\mathrm{SDR})+\beta_{3}(\mathrm{TDR})+\beta_{4}(\mathrm{FDR})+\beta_{5}(\mathrm{SIZE})+\beta_{6}(\mathrm{AGE})+\beta_{7}(\mathrm{GROW})+\beta_{8}(\mathrm{LEV})+\varepsilon$

$\mathrm{ROA}=\beta_{0}+\beta_{1}(\mathrm{INDR})+\beta_{2}(\mathrm{SDR})+\beta_{3}(\mathrm{TDR})+\beta_{4}(\mathrm{FDR})+\beta_{5}(\mathrm{SIZE})+\beta_{6}(\mathrm{AGE})+\beta_{7}(\mathrm{GROW})+\beta_{8}(\mathrm{LEV})+\varepsilon$

$\mathrm{ROE}=\beta_{0}+\beta_{1}(\mathrm{INDR})+\beta_{2}(\mathrm{SDR})+\beta_{3}(\mathrm{TDR})+\beta_{4}(\mathrm{FDR})+\beta_{5}(\mathrm{SIZE})+\beta_{6}(\mathrm{AGE})+\beta_{7}(\mathrm{GROW})+\beta_{8}(\mathrm{LEV})+\varepsilon$

$\mathrm{BEP}=\beta_{0}+\beta_{1}(\mathrm{INDR})+\beta_{2}(\mathrm{SDR})+\beta_{3}(\mathrm{TDR})+\beta_{4}(\mathrm{FDR})+\beta_{5}(\mathrm{SIZE})+\beta_{6}(\mathrm{AGE})+\beta_{7}(\mathrm{GROW})+\beta_{8}(\mathrm{LEV})+\varepsilon$

ii. Shareholding Position and Firm Profitability

$\mathrm{EPS}=\beta_{0}+\beta_{1}(\mathrm{SPD})+\beta_{2}(\mathrm{INST})+\beta_{3}(\mathrm{FOR})+\beta_{4}(\mathrm{PUB})+\beta_{5}(\mathrm{SIZE})+\beta_{6}(\mathrm{AGE})+\beta_{7}(\mathrm{GROW})+\beta_{8}(\mathrm{LEV})+\varepsilon$

$\mathrm{NPM}=\beta_{0}+\beta_{1}(\mathrm{SPD})+\beta_{2}(\mathrm{INST})+\beta_{3}(\mathrm{FOR})+\beta_{4}(\mathrm{PUB})+\beta_{5}(\mathrm{SIZE})+\beta_{6}(\mathrm{AGE})+\beta_{7}(\mathrm{GROW})+\beta_{8}(\mathrm{LEV})+\varepsilon$

$\mathrm{ROA}=\beta_{0}+\beta_{1}(\mathrm{SPD})+\beta_{2}(\mathrm{INST})+\beta_{3}(\mathrm{FOR})+\beta_{4}(\mathrm{PUB})+\beta_{5}(\mathrm{SIZE})+\beta_{6}(\mathrm{AGE})+\beta_{7}(\mathrm{GROW})+\beta_{8}(\mathrm{LEV})+\varepsilon$

$\mathrm{ROE}=\beta_{0}+\beta_{1}(\mathrm{SPD})+\beta_{2}(\mathrm{INST})+\beta_{3}(\mathrm{FOR})+\beta_{4}(\mathrm{PUB})+\beta_{5}(\mathrm{SIZE})+\beta_{6}(\mathrm{AGE})+\beta_{7}(\mathrm{GROW})+\beta_{8}(\mathrm{LEV})+\varepsilon$

$\mathrm{BEP}=\beta_{0}+\beta_{1}(\mathrm{SPD})+\beta_{2}(\mathrm{INST})+\beta_{3}(\mathrm{FOR})+\beta_{4}(\mathrm{PUB})+\beta_{5}(\mathrm{SIZE})+\beta_{6}(\mathrm{AGE})+\beta_{7}(\mathrm{GROW})+\beta_{8}(\mathrm{LEV})+\varepsilon$

Where, $\beta_{0}=$ Intercept coefficient (constant); $\beta_{\mathrm{i}}=$ Coefficient of each independent and control variables

INDR $=$ Number of independent directors in the corporate body

$\mathrm{SDR}=$ Number of shareholder directors in the corporate body

$\mathrm{TDR}=$ Total members in the corporate body

$\mathrm{FDR}=$ Number of female members in the corporate body

$\mathrm{SPD}=$ Share held by the sponsors and/or directors (\%)

INST $=$ Share held by institutional investors (\%)

$\mathrm{FOR}=$ Share held by foreigners $(\%)$

$\mathrm{PUB}=$ Share held by the general public $(\%)$

$\varepsilon=$ Error term 


\section{Results and Discussions}

Table 4: Descriptive results

\begin{tabular}{lrrrr}
\hline Variables & Minimum & \multicolumn{1}{c}{ Maximum } & \multicolumn{1}{c}{ Mean } & Std. Deviation \\
\hline EPS & -3.84 & 86.14 & 10.633 & 19.419 \\
NPM & -279.36 & 29.50 & -2.846 & 58.687 \\
ROA & -17.78 & 40.87 & 6.652 & 10.261 \\
ROE & -24.23 & 120.10 & 20.179 & 33.461 \\
BEP & -11.62 & 55.64 & 9.253 & 13.047 \\
INDR & 1.00 & 3.00 & 1.992 & 0.546 \\
SDR & 1.00 & 8.00 & 4.484 & 1.656 \\
TDR & 5.00 & 12.00 & 7.476 & 1.859 \\
FDR & 0.00 & 5.00 & 1.927 & 1.458 \\
SPD & 12.01 & 90.00 & 44.376 & 19.672 \\
INST & 4.55 & 43.73 & 17.178 & 9.599 \\
FOR & 0.00 & 38.05 & 3.220 & 8.375 \\
PUB & 1.05 & 68.86 & 35.036 & 17.865 \\
AGE & 11 & 72 & 35.000 & 18.327 \\
SIZE & 18.30 & 24.46 & 22.001 & 1.550 \\
GROW & -39.78 & 27.21 & 1.025 & 17.953 \\
LEV & 0.02 & 6.18 & 1.231 & 1.301 \\
\hline
\end{tabular}

The descriptive results shown in Table 2 represent the lowest, highest, average and standard deviation values of all defined variables. Results of all the dependent variables are dispersed extensively from the mean. As a result, the standard deviations of these variables are greater than the mean values. On average, the listed pharmaceutical and chemical companies have produced negative NPM $(-2.846 \%)$ with a standard deviation of $58.687 \%$, which is too high. The firms have gained an earning of taka 10.633 per share (on average) and ROA of 6.652 percent (on average). The basic earning capability over total assets stands at 9.253 percent (on average). Among the profitability indicators, ROE shows the most positive result (mean of $20.179 \%$ with a standard deviation of $33.446 \%$ ). Though the result carries a high degree of deviation, the sector has performed the best in gaining return against the shareholder's equity.

The average board size stands at 7.476 persons comprise mostly (on average 4.484) with the inside ownership (sponsors and promoters). Jensen (1986) prescribes for maximum 7 to 8 board members for ideal performance. Hence, the mean board size of the companies is optimally designed for better firm profitability. However, average participation of independent directors and female directors is relatively low (1.992 and 1.927 respectively). It may impact negatively in securing general investor's rights and knowledge diversity.

The sponsors and/or directors, and general public hold almost 80 percent of the shares (on average 44.376 and 35.036 percent respectively). The institutes also hold a significant portion of shares (17.178 percent on average). Foreign investor's participation is significantly low (mean value of 3.220 percent). In addition, the companies listed under the pharmaceutical and chemical sector have noteworthy experience in business operations (on average 35 years). The sector also experiences a sales growth of 1.025 percent over the study period.

\subsection{Corporate Profile and Firm Profitability}

\subsubsection{Correlation Coefficient}

Table 5: Correlation coefficient of corporate profile and firm profitability

\begin{tabular}{|c|c|c|c|c|c|c|c|c|c|c|}
\hline & & EPS & NPM & ROA & ROE & BEP & INDR & SDR & TDR & FDR \\
\hline $\begin{array}{l}\text { EPS } \\
\end{array}$ & Pear. Corr. & 1 & & & & & & & & \\
\hline NPM & Pear. Corr. & .195 & 1 & & & & & & & \\
\hline $\mathrm{ROA}$ & Pear. Corr. & $.679^{* * *}$ & $.630^{* * *}$ & 1 & & & & & & \\
\hline ROE & Pear. Corr. & $.611^{* * *}$ & $-.349^{*}$ & $.392^{* *}$ & 1 & & & & & \\
\hline BEP & Pear. Corr. & $.790^{* * *}$ & $.432^{* *}$ & $.937^{* * *}$ & $.481^{* * *}$ & 1 & & & & \\
\hline INDR & Pear. Corr. & .168 & .252 & .284 & -.098 & $.360^{* *}$ & 1 & & & \\
\hline SDR & Pear. Corr. & .124 & .118 & .073 & -.018 & .121 & .230 & 1 & & \\
\hline TDR & Pear. Corr. & .160 & .180 & .148 & -.045 & .214 & $.499^{* * *}$ & $.958^{* * *}$ & 1 & \\
\hline FDR & Pear. Corr. & -.158 & .183 & -.136 & $-.304^{*}$ & -.202 & .109 & $.464^{* * *}$ & $.445^{* *}$ & 1 \\
\hline
\end{tabular}

${ }^{* * * *}$ sig. at $0.01,{ }^{* *}$ sig. at 0.05 and ${ }^{*}$ sig. at 0.10 . Pear. Corr. stands for Pearson correlation

The correlation analysis (shown in Table 3 ) between dependent and selected independent variables establishes the relationship of corporate profile and firm profitability. All the dependent variables are positively correlated among themselves except for ROE and NPM pair, which has a low degree of negative correlation (-0.349 with a significance level of 0.10). However, NPM and EPS matrix are not significantly correlated. ROA-EPS, ROA- 
NPM, and ROE-EPS pairs have a moderate degree of positive correlation, while BEP-EPS, and BEP-ROA pairs have a very strong positive association. ROE and ROA share a low degree of positive relationships. These six matrices are significant either at $1 \%$ level or at $5 \%$ level.

Correlations between dependent and independent variables are negligible except for INDR and BEP, and FDR and ROE matrices. INDR and BEP is positively correlated, while FDR and ROE has negative correlation. Whilst, there is a low degree of correlation. Therefore, an increase in independent director results to a slight increase in firms earning power, and an increase in female members in BoDs results to a slight decrease in return on shareholder's equity.

Among the independent variables, TDR and INDR, TDR and SDR, FDR and SDR, and FDR and TDR matrices have significant positive coefficients in which TDR and SDR share a very high degree of correlation. In result, inside directors (i.e. promoters and sponsors) own a significant portion of the board. The other relationships are insignificant.

4.1.2 Regression Model

Table 6: OLS Regression model summary

\begin{tabular}{|c|c|c|c|c|}
\hline Model & $\mathrm{R}$ & R Square & Adj. R Square & Std. Error \\
\hline 1 & $.556^{\mathrm{a}}$ & .309 & .099 & 18.429 \\
\hline 2 & $.319^{\mathrm{a}}$ & .101 & -.172 & 63.534 \\
\hline 3 & $.352^{\mathrm{a}}$ & .124 & -.142 & 10.967 \\
\hline 4 & $.492^{\mathrm{a}}$ & .242 & -.011 & 33.278 \\
\hline 5 & $.508^{\mathrm{a}}$ & .258 & .033 & 12.833 \\
\hline
\end{tabular}

Table 7: Regression results

\begin{tabular}{lrrrrr}
\hline Variables & \multicolumn{1}{c}{ Model 1 } & \multicolumn{1}{c}{ Model 2 } & \multicolumn{1}{c}{ Model 3 } & \multicolumn{1}{c}{ Model 4 } & \multicolumn{1}{c}{ Model 5 } \\
\hline Constant & -13.286 & -135.126 & -6.633 & 38.516 & 6.664 \\
& $(52.561)$ & $(181.198)$ & $(31.277)$ & $(94.910)$ & $(36.599)$ \\
\hline \multirow{2}{*}{ INDR } & 6.277 & 25.036 & 5.145 & -5.288 & $8.340^{*}$ \\
& $(6.510)$ & $(22.443)$ & $(3.874)$ & $(11.755)$ & $(4.533)$ \\
\hline \multirow{2}{*}{ SDR } & .993 & .760 & .521 & 1.908 & .944 \\
& $(2.476)$ & $(8.536)$ & $(1.473)$ & $(4.471)$ & $(1.724)$ \\
\hline \multirow{2}{*}{ FDR } & $-5.271^{*}$ & 7.644 & -1.642 & $-10.874^{* *}$ & $-3.419^{*}$ \\
& $(2.704)$ & $(9.323)$ & $(1.609)$ & $(4.883)$ & $(1.883)$ \\
\hline \multirow{2}{*}{ AGE } & $.383^{*}$ & -.361 & .018 & .168 & .162 \\
& $(.219)$ & $(.754)$ & $(.130)$ & $(.395)$ & $(.152)$ \\
\hline \multirow{2}{*}{ SIZE } & -.038 & 3.532 & .117 & -.589 & -.814 \\
& $(2.374)$ & $(8.185)$ & $(1.413)$ & $(4.287)$ & $(1.653)$ \\
\hline \multirow{2}{*}{ GROW } & -.090 & -.049 & .034 & .247 & .030 \\
& $(.206)$ & $(.710)$ & $(.123)$ & $(.372)$ & $(.143)$ \\
\hline \multirow{2}{*}{ LEV } & 3.766 & -.638 & .501 & $9.280^{*}$ & .458 \\
& $(2.865)$ & $(9.876)$ & $(1.705)$ & $(5.173)$ & $(1.995)$ \\
\hline
\end{tabular}

${ }^{* *}$ sig. at 0.05 level, ${ }^{*}$ sig. at 0.10 level. Notes: Excluded TDR. Std. errors in parentheses.

The regression model summary (shown in Table 4) prescribes R square of 30.9, 10.1, 12.4, 24.2 and 25.8 percent variations of firm profitability (EPS, NPM, ROA, ROE and BEP respectively) can be interpreted by the experimental variables. Most of the R square results are too small to competently define the respective regression models. TDR has been excluded from the analysis due to insignificance, while Kumar and Singh (2013) concludes its significant positive effect. Most of the variables express insignificant effect on the regression models designed to determine firm profitability as affected by corporate profile (Table 5). INDR significantly and positively affects Model 5 (coefficient of 8.340 at 0.10 level of sig.). It represents that the participation of independent directors increases the firm's BEP that leads to a positive result on firm profitability. The conclusion is corresponding to the findings of Yameen et al. (2009); Arora and Sharma (2015) and Uadiale (2010). However, Farhan et al. (2020) conclude the opposite findings studying the Indian pharmaceutical industry. Though the participation of female members in the BoDs leads to knowledge diversity and wider resource accessibility, this study illustrates significant negative impacts of female directors on regression Model 1, Model 4 and Model 5. An increase of female members in the board by $2.704,4.883$ and 1.883 leads to a decrease of EPS, ROE and BEP by 5.271, 10.874 and 3.419 percent respectively. Therefore, this study concludes that the participation of women in BoDs reduces firm profitability. However, Chancharat and Chancharat (2019) suggest no significant affiliation of female directors and firm profitability. 


\subsection{Shareholding Position and Profitability}

\subsubsection{Correlation Coefficient}

Table 8: Correlation coefficient of shareholding position and firm profitability

\begin{tabular}{|c|c|c|c|c|c|c|c|c|c|c|}
\hline & & EPS & NPM & ROA & $\mathrm{ROE}$ & BEP & SPD & INST & FOR & PUB \\
\hline EPS & Pear. Corr. & 1 & & & & & & & & \\
\hline NPM & Pear. Corr. & .195 & 1 & & & & & & & \\
\hline $\mathrm{ROA}$ & Pear. Corr. & $.679^{* * *}$ & $.630^{* * *}$ & 1 & & & & & & \\
\hline ROE & Pear. Corr. & $.611^{* * *}$ & $-.349^{*}$ & $.392^{* *}$ & 1 & & & & & \\
\hline BEP & Pear. Corr. & $.790^{* * *}$ & $.432^{* *}$ & $.937^{* * *}$ & $.481^{* * *}$ & 1 & & & & \\
\hline SPD & Pear. Corr. & $.609^{* * *}$ & .121 & $.378^{* *}$ & $.440^{* *}$ & $.465^{* * *}$ & 1 & & & \\
\hline INST & Pear. Corr. & $-.302^{*}$ & .065 & -.140 & -.312 & -.192 & $-.482^{* * *}$ & 1 & & \\
\hline FOR & Pear. Corr. & .179 & .124 & .177 & -.016 & .169 & -.180 & .029 & 1 & \\
\hline PUB & Pear. Corr. & $-.618^{* * *}$ & -.228 & $-.433^{* *}$ & $-.330^{*}$ & $-.496^{* * *}$ & $-.773^{* * *}$ & -.007 & -.285 & 1 \\
\hline
\end{tabular}

${ }^{* * * *}$ sig. at $0.01,{ }^{* *}$ sig. at 0.05 and ${ }^{*}$ sig. at 0.10 . Pear. Corr. stands for Pearson correlation

The correlation table (Table 6) denotes that SPD has a significant effect on EPS (moderately positive at $0.609)$, and a low degree of positive on ROA, ROE and BEP $(0.378,0.440$ and 0.465 respectively). In other means, SPD brings a positive outcome on firm profitability. INST has a negative (low degree: -0.302) association with firm EPS. Hence, an increase in the proportion of institutional shareholding indicates a slight decline in firm's EPS. The other correlation metrics of INST are insignificant suggesting no notable effect on firm profitability. Foreign investors owe a small proportion of total shares, and their effect on firm profitability is negligible as states in FOR variable of the table. PUB produces significant negative results on firm profitability. The variable has a moderate negative correlation with EPS (-0.618), and a low degree of negative correlation with ROA, ROE and BEP (-0.433, -0.330 , and -0.496 respectively). However, its effect on NPM is insignificant. In turn, firms with a higher percentage of shareholding by the sponsors and directors experience greater positive results, while a higher percentage of shareholding by the general public produces more negative effects on firm profitability. 4.2.2 Regression Model

Table 9: Regression model summary

\begin{tabular}{crrrr}
\hline Model & R & R Square & Adj. R Square & \multicolumn{1}{c}{ Std. Error } \\
\hline 6 & $.811^{\mathrm{a}}$ & .658 & .534 & 13.253 \\
7 & $.310^{\mathrm{a}}$ & .096 & -.233 & 65.159 \\
8 & $.578^{\mathrm{a}}$ & .334 & .092 & 9.776 \\
9 & $.588^{\mathrm{a}}$ & .346 & .108 & 31.606 \\
10 & $.635^{\mathrm{a}}$ & .407 & .187 & 11.767 \\
\hline
\end{tabular}

a. Predictors: (Constant), GROW, INST, AGE, FOR, PUB, SIZE, SPD and LEV

Table 10: OLS Regression results

\begin{tabular}{lrrrrr}
\hline Variables & \multicolumn{1}{c}{ Model 6 } & \multicolumn{1}{c}{ Model 7 } & \multicolumn{1}{c}{ Model 8} & \multicolumn{1}{c}{ Model 9 } & \multicolumn{1}{c}{ Model 10 } \\
\hline \multirow{2}{*}{ Constant } & $1240.093^{* * *}$ & 923.366 & 346.622 & $1748.768^{*}$ & 290.010 \\
& $(382.124)$ & $(1878.694)$ & $(281.862)$ & $(911.272)$ & $(339.284)$ \\
\hline \multirow{2}{*}{ SPD } & $-11.630^{* * *}$ & -7.596 & -2.928 & $-16.788^{*}$ & -2.086 \\
& $(3.694)$ & $(18.163)$ & $(2.725)$ & $(8.810)$ & $(3.280)$ \\
\hline \multirow{2}{*}{ INST } & $-11.958^{* * *}$ & -6.695 & -2.989 & $-17.437^{*}$ & -2.275 \\
& $(3.597)$ & $(17.682)$ & $(2.653)$ & $(8.577)$ & $(3.193)$ \\
\hline \multirow{2}{*}{ FOR } & $-11.464^{* * *}$ & -6.841 & -2.814 & $-17.103^{*}$ & -1.998 \\
& $(3.656)$ & $(17.974)$ & $(2.697)$ & $(8.718)$ & $(3.246)$ \\
\multirow{2}{*}{ PUB } & $-12.234^{* * *}$ & -8.638 & -3.273 & $-17.419^{*}$ & -2.576 \\
& $(3.687)$ & $(18.238)$ & $(2.720)$ & $(8.793)$ & $(3.274)$ \\
\multirow{2}{*}{ AGE } & .150 & -.342 & -.070 & -.271 & .031 \\
& $(.150)$ & $(.737)$ & $(.111)$ & $(.350)$ & $(.133)$ \\
\hline \multirow{2}{*}{ SIZE } & -1.998 & -6.105 & -1.367 & -.501 & -2.257 \\
& $(2.235)$ & $(11.181)$ & $(1.677)$ & $(5.423)$ & $(2.019)$ \\
\hline \multirow{2}{*}{ GROW } & .023 & .391 & .106 & .271 & .116 \\
& $(.147)$ & $(.721)$ & $(.108)$ & $(.350)$ & $(.130)$ \\
\hline \multirow{2}{*}{ LEV } & -3.012 & -2.830 & -2.052 & -.523 & -3.232 \\
& $(2.235)$ & $(10.987)$ & $(1.648)$ & $(5.329)$ & $(1.984)$ \\
\hline
\end{tabular}

${ }^{* * *}$ sig. at 0.01 level ${ }^{* *}$ sig. at 0.05 level and ${ }^{*}$ sig. at 0.10 level. Note: Std. errors in parentheses. 
Tables 7 reveals that $65.8,9.6,33.4,34.6$ and 40.7 percent variations of firm profitability (EPS, NPM, ROA, ROE and BEP respectively) can be explained by the experimental variables. The significant negative coefficients of SPD, INST, FOR and PUB for Model 6 and Model 9 suggest that all the independent variables negatively affect EPS and ROE (Table 8). The results infer that the increase of shareholding percentage reduces firm profitability. However, their effects on other models are negative but insignificant. The greatest significant negative impact on firm profitability has been encountered from general investor's shareholding ( -12.234 on EPS) and institutional shareholding (-17.437 on ROE). The findings infer that the higher the percentage of public and institutional shareholding, the lower the firm EPS and ROE respectively. The foreign investors produce the least degree of noteworthy negative impact on EPS, and the sponsors and/or directors on ROE (-11.464 and -16.788 respectively). The study outcomes are similar to the conclusions of Uadiale (2010) and Kumar and Singh (2013) [SPD and profitability]; Fauzi and Lock (2012) and Hossain et al. (2001) [INST and profitability].

\subsection{Hypothesis Testing}

Table 11: Hypothesis testing and results

\begin{tabular}{|c|c|c|c|c|c|c|c|}
\hline \multirow[t]{2}{*}{ Hypotheses } & \multicolumn{5}{|c|}{ Results } & \multirow[t]{2}{*}{ Tools } & \multirow{2}{*}{ Effect on firm profitability } \\
\hline & EPS & NPM & ROA & $\mathrm{ROE}$ & $\mathrm{BEP}$ & & \\
\hline $\mathrm{H}_{1}$ & $\mathrm{R}$ & $\mathrm{R}$ & $\mathrm{R}$ & $\mathrm{R}$ & $\mathrm{R}$ & Correlation & No significant relationship \\
\hline $\mathrm{H}_{2}$ & $\mathrm{R}$ & $\mathrm{R}$ & $\mathrm{R}$ & $\mathrm{R}$ & A & Regression & Significantly positive with BEP \\
\hline $\mathrm{H}_{3}$ & A & $\mathrm{R}$ & $\mathrm{R}$ & A & A & Regression & $\begin{array}{l}\text { Significantly negative with EPS, } \\
\text { ROE and BEP }\end{array}$ \\
\hline $\mathrm{H}_{4}$ & $\mathrm{R}$ & $\mathrm{R}$ & $\mathrm{R}$ & $\mathrm{R}$ & $\mathrm{R}$ & Regression & No significant relationship \\
\hline $\mathrm{H}_{5}$ & A & $\mathrm{R}$ & $\mathrm{R}$ & A & $\mathrm{R}$ & Regression & $\begin{array}{l}\text { Significantly negative with EPS } \\
\text { and ROE }\end{array}$ \\
\hline $\mathrm{H}_{6}$ & A & $\mathrm{R}$ & $\mathrm{R}$ & A & $\mathrm{R}$ & Regression & $\begin{array}{l}\text { Significantly negative with EPS } \\
\text { and ROE }\end{array}$ \\
\hline $\mathrm{H}_{7}$ & A & $\mathrm{R}$ & $\mathrm{R}$ & A & $\mathrm{R}$ & Regression & $\begin{array}{l}\text { Significantly negative with EPS } \\
\text { and ROE }\end{array}$ \\
\hline $\mathrm{H}_{8}$ & A & $\mathrm{R}$ & A & A & A & $\begin{array}{l}\text { Correlation and/or } \\
\text { regression }\end{array}$ & $\begin{array}{l}\text { Significantly negative with EPS, } \\
\text { ROA, ROE and BEP }\end{array}$ \\
\hline
\end{tabular}

Note: $\mathrm{A}=$ Alternative hypothesis is accepted, $\mathrm{R}=$ Alternative Hypothesis is rejected

Though different studies suggest both positive and negative effects of number of board members on firm profitability, this study finds no significant impact. Consequently, the first hypothesis $\left(\mathrm{H}_{1}\right)$ is rejected. The effect is so insignificant that the variable is excluded in regression results. Board composition of many firms in Bangladesh bears evidence that the sponsors or promoters, backed by their significant shareholding power, appoint their family members and relatives in the board. Several firms considered for this study consist of a significant portion of family members and relatives in the corporate body. As a result, the board size may increase in numbers but the decision may be executed by the sponsors or promoters. This may be a possible explanation of the insignificant results of board size in listed pharmaceutical and chemical companies of Bangladesh.

Independent directors are considered as the prime movers for ensuring transparency and corporate governance. As they have no conflict of interest with the firm's operations, they can protect the general shareholder's rights at most. However, their functionality mostly depends on their willingness and presence of true independence (Chancharat and Chancharat, 2019). The independent director's participation significantly and positively affects BEP, while relationships with other measurements (EPS, NPM, ROA and ROE) remain insignificant. So, the study accepts the second hypothesis $\left(\mathrm{H}_{2}\right)$. Though the participation of more independent directors brings more positive results to firm profitability, their functionality remains questionable considering the coefficients of EPS, NPM, ROA and ROE. Many firms, especially the family-based, either select favourable persons as independent directors or restrict their independence to a great extent. In consequence, they might not or could not play factual roles to bring greater firm profitability by reducing agency problems, conflict of interests and so on hitches.

The regression results illustrate a negative impact of female members in the corporate body on firm profitability; therefore, the third hypothesis $\left(\mathrm{H}_{3}\right)$ is accepted. However, the result is opposite to the research conducted by Jurkus et al. (2008); Carter et al. (2003) and Bonn (2004). The presence of female members signifies negative outcomes on EPS, ROE and BEP. It implies that organisational profitability reduces with the increase of female members in the board. However, their effect on NPM and ROA is negligible. In many cases, the sponsors and promoters appoint their spouse and siblings as female directors in pen and paper but the real decision is executed by the male dominated board. The female directors sometimes act as sleeping members of the board. Chiefly, these could be the possible reasons of their negative association.

The study implies no evidence of sponsor's and promoter's impact on organisation profitability due to the insignificant probability of regression analysis. For instance, the fourth hypothesis $\left(\mathrm{H}_{4}\right)$ is rejected. The result is 
consistent with the judgements prescribed by Abidin et al. (2009). However, the findings contradict the studies with positive effects conducted by McConnell and Servaes (1990), and with negative effects led by Demsetz (1983). Though the sponsors' and promoters' participation in the board did not produce any negative result, they neither did bring notable positive results to the firm. Hence, the general shareholder may draw questionable assumptions regarding their role and willingness toward alignment effect that supports maximising firm value.

All the hypotheses $\left(\mathrm{H}_{5}, \mathrm{H}_{6}, \mathrm{H}_{7}\right.$ and $\left.\mathrm{H}_{8}\right)$ designed to examine the effect of shareholding position denote significant negative results. Though SPD is positively correlated with EPS, ROA, ROE and BEP (Table 6), shareholding of sponsors and directors, institutions, foreign investors and public investors signify negative impacts on EPS and ROE (Table 8). Hence, all of these hypotheses are accepted. The negative association of all existing shareholding pattern suggests to thrive for new sources of investment to bring positive outcome. The other three dependent variables have no significant relationship with the shareholding pattern. However, the degree of influence is not the same for SPD, INST, FOR and PUB. The study findings of $\mathrm{H}_{5}$ contradict the negative association stated by Uadiale (2010). $\mathrm{H}_{5}, \mathrm{H}_{6}, \mathrm{H}_{7}$ and $\mathrm{H}_{8}$ are opposite with the conclusions of Cho and Kim (2007), while $\mathrm{H}_{7}$ is aligned with the findings of Akintoye (2008). In addition, public shareholding $\left(\mathrm{H}_{8}\right)$ shares significant negative links with all the dependent variables except NPM. Hence, the study suggests to keep the percentage of public shareholding as low as possible to ensure maximum firm profitability.

The regression results represent that the independent and control variables have no significant relationship with NPM and ROA. Hence, the effect of corporate profile and shareholding position on firm profitability cannot be illustrated by the results of NPM and ROA. Chancharat and Chancharat (2019) notice the same conclusion between corporate profile and ROA. From the study, it can be interpreted that the listed pharmaceutical and chemical companies of Bangladesh did not produce significant profit margin over sales and return over assets which can illustrate the importance of board variation and ownership concentration.

\section{Conclusion and Scope for Future Study}

Investors want to be confident considering an organisation's financial strength, transparency and corporate governance practices before making their investment. The effects of different organisational mechanisms on financial performance and governance are paramount in investment decision. Corporate profile and shareholding structure are such important factors that affect firm profitability. The study postulates only positive effect of independent directors on firm profitability (using BEP). The other variables indicate negative associations. The greater members of female members in corporate bodies produces greater negative results for the firm (using EPS, ROE and BEP). Therefore, further studies are encouraged to unleash the reasons of negative impact caused by participation of female directors and to postulate their possible remedies. The Association of sponsors and promoters in BoDs brings no significant outcome. All forms of the existing shareholding structure of the selected companies produce negative impact on profitability (using EPS and ROE). However, the general public and institutional investors affect the most, while foreign investors affect the least. Consequently, the firms can create more desired profitability by increasing proportion of dedicated independent directors subject to ensuring their true independence, and engaging more foreign investors. Nevertheless, the negative association of existing shareholding position instigates to opt for new sources of quality investment with capability to en route the firm profitability in positive direction. Further study is encouraged to explore such investment sources. Though the average size of corporate bodies in the selected firms is optimal, the empirical results suggest an insignificant effect. Despite most of the members of BoDs are sponsors and promoters, the study finds no significant relationship to delineate firm profitability. The R square results associated with regression models of corporate profile and firm profitability reveal the need for further studies with more variables or more observations. In addition, two measurements - NPM and ROA - signify no meaningful effect on the models developed to determine firm profitability. In this regard, further study is encouraged to define the insight causes of their insignificance. Alternatively, research can be explored in the same organisation with more control variables and tools to demonstrate whether board size, and sponsor's or promoter's participation in the board signifies any effect on firm profitability measurement. Furthermore, corporate profile and shareholding position can also be studied with wider moderating factors and observations for the better understanding their effect on return on assets and net profit margin.

\section{References}

Abidin, Z.Z, Kamal, N.M. and Jusoff, K. (2009) 'Board structure and corporate performance in Malaysia', International Journal of Economics and Finance, Vol. 1 No.1, pp.150-164.

Adams, R.B. and Santos, J.A. (2006) 'Identifying the effect of managerial control on firm performance', Journal of Accounting and Economics, Vol. 41 No.1-2, pp.55-85.

Adams, R.B. and Ferreira, D. (2009) 'Women in the boardroom and their impact on governance and performance', Journal of Financial Economics, Vol. 94 No.2, pp.291-309.

Afrifa, G.A. (2016) 'Net working capital, cash flow and performance of UK SMEs', Review of Accounting and 
Finance, Vol. 15 No.1, pp.21-44.

Akintoye, I.R. (2008) 'Effect of capital structure on firms' performance: the Nigerian experience', European Journal of Economics, Finance and Administrative Sciences, Vol. 10, pp.233- 243.

Arora, A. and Sharma, C. (2015) 'Impact of firm performance on board characteristics: Empirical evidence from India', IIM Kozhikode Society and Management Review, Vol. 4 No.1, pp.53-70.

Baek, J.S., Kang, J.K. and Park, K.S. (2004) 'Corporate governance and firm value: evidence from the Korean financial crisis’, Journal of Financial Economics, Vol. 71, pp.265-313.

Baker, M. and Wurgler, J. (2006) 'Investor sentiment and the cross - section of stock returns', The Journal of Finance, Vol 61 No.4, pp.1645-1680.

Bangladesh Securities and Exchange Commission. (2018). Corporate Governance Code. https://www.google.com/url?sa=tandrct=jandq=andesrc=sandsource=webandcd=andved=2ahUKEwiSgb2 $\mathrm{m}$ pIfxAhUeILcAHeNvCKkQFjAAegQIAhADandurl=https\%3A\%2F\%2Fwww.sec.gov.bd\%2Fslaws\%2FCor porate_Governance_Code_10.06.2018.pdfandusg=AOvVaw3OD_4do8yD0Sg8o0UKgHzh. (Accessed 1 May 2021)

Bhagat, S. and Black, B. (2002) 'The non-correlation between board independence and long-term firm performance', Journal of Corporation Law, Vol. 27 No.2, pp.231-273.

Black, B. and Kim, W. (2012) 'The effect of board structure on firm value: A multiple identification strategies approach using Korean data', Journal of Financial Economics, Vol. 104 No.1, pp.203-226.

Bonn, I. (2004) 'Board structure and firm performance: Evidence from Australia', Journal of Management and Organisation, Vol. 10 No.1, pp.14-24.

Boubraki, N., Cosset, J.C. and Guedhami, O. (2005) 'Post privatization corporate governance: The role of ownership structure and investor protection', Journal of Financial Economics, Vol. 76 No.2, pp.369-399.

Brigham, E.F. and Houston, J.F. (2012) Fundamentals of Financial Management, $10^{\text {th }}$ ed., Thomson South Western, Ohio.

Carter, D.A., Simkins, B.J. and Simpson, W.G. (2003) 'Corporate governance, board diversity, and firm value', Financial Review, Vol. 38, pp.33-53.

Chancharat, S. and Chancharat, N. (2019) 'Board structure, ownership structure, and performance of Thai listed companies', Australasian Accounting, Business and Finance Journal, Vol. 13 No.3, pp.53-70.

Chibber, P.K. and Majumdar, S.K. (1999) 'Foreign ownership and profitability: property rights, control and the performance of firms in Indian industry', Journal of Law and Economics, Vol. 42, pp.209-238.

Cho, D.S. and Kim, J. (2007) 'Outside directors, ownership structure and firm profitability in Korea', Corporate Governance: An International Review, Vol. 15 No.2, pp.239-250.

Coles, J.L., Daniel, N.D. and Naveen, L. (2008) 'Boards: Does one size fit all?', Journal of Financial Economics, Vol. 87 No.2, pp.329-356.

Dehaene, A., De Vuyst, V. and Ooghe, H. (2001) 'Corporate performance and board structure in Belgian companies', Long Range Planning, Vol. 34 No.3, pp.383-398.

Demsetz, H. (1983) 'The structure of ownership and the theory of the firm', The Journal of Law and Economics, Vol. 26 No.2, pp.375-390.

Douma, S., George, R. and Kabir, R. (2006) 'Foreign and domestic ownership, business groups, and firm performance: Evidence from a large emerging market', Strategic Management Journal, Vol. 27 No.7, pp.637657.

Earle, J.S., Kucsera, C. and Telegdy, A. (2005) 'Ownership concentration and corporate performance on the Budapest Stock Exchange: Do too many cooks spoil the goulash?', Corporate Governance: An International Review, Vol. 13 No.2, pp.254-264.

Ehikioya, B.I. (2009) 'Corporate governance structure and firm performance in developing economies: Evidence from Nigeria', Corporate Governance: The International Journal of Business in Society, Vol. 9 No.3, pp.231243.

Erickson, J., Park, Y.W., Reising, J. and Shin, H.H. (2005) 'Board composition and firm value under concentrated ownership: the Canadian evidence', Pacific-Basin Finance Journal, Vol. 13 No.4, pp.387-410.

Farhan, N., Tabash, M., Almaqtari, F. and Yahya, A. (2020) 'Board composition and firms' profitability: Empirical evidence from pharmaceutical industry in India'. Journal of International Studies, Vol. 13 No.3, pp.180-194.

Fauzi, F. and Locke, S. (2012). 'Board Structure, ownership structure and firm performance: A study of New Zealand listed-firms', Asian Academy of Management Journal of Accounting and Finance (AAMJAF), Vol. 8 No.2, pp.43-67.

Fich, E.M. and Shivdasani, A. (2006) 'Are busy boards effective monitors?', The Journal of Finance, Vol. 61 No.2, pp.689-724.

Hamid, M.A., Abdullah, A. and Kamaruzzaman, N.A. (2015) 'Capital structure and profitability in family and non-family firms: Malaysian evidence', Procedia Economics and Finance, Vol. 31, pp.44-55.

Haniffa, R. and Hudaib, M. (2006) 'Corporate governance structure and performance of Malaysian listed 
companies', Journal of Business Finance and Accounting, Vol. 33 No.7, pp.1034-1062.

Hartzell, J.C. and Starks, L.T. (2003) 'Institutional investors and executive compensation', The Journal of Finance, Vol. 58 No.6, pp.2351-2374.

Hossain, M., Prevost, A.K. and Rao, R.P. (2001) 'Corporate governance in New Zealand: The effect of the 1993 Companies Act on the relation between board composition and firm performance', Pacific-Basin Finance Journal, Vol. 9, pp.119-145.

Hu, H.W., Tam, O.K. and Tan, M.G.S. (2010) 'Internal governance mechanisms and firm performance in China', Asia Pacific Journal Management, Vol. 27 No.4, pp.727-749.

Jensen, M.C. (1986) 'Agency costs of free cash flow, corporate finance, and takeovers', American Economic Review, Vol. 76, pp.323-329.

Jensen, M.C. and Meckling, W.H. (1976) 'Theory of the firm: managerial behaviour, agency cost and ownership structure', Journal of Financial Economics, Vol. 3 No.4, pp.305-360.

Jurkus, A.F., Park, J.C. and Woodard, L.S. (2008) 'Gender Diversity, firm performance, and environment', SSRN Working Paper, 28 February.

Kapoor, N. and Goel, S. (2017) 'Board characteristics, firm profitability and earnings management: Evidence from India', Australian Accounting Review, Vol. 27 No.2, pp.180-194.

Klein, A. (2002) 'Audit committee, board of directors' characteristics, and earnings management', Journal of Accounting and Economics, Vol. 33 No.3, pp.375-400.

Kumar, N. and Singh, J.P. (2013) 'Effect of board size and promoter ownership on firm value: Some empirical findings from India', Corporate Governance: The International Journal of Business in Society, Vol. 13 No.1, pp.88-98.

Lim, H. and Rokhim, R. (2020) 'Factors affecting profitability of pharmaceutical company: an Indonesian evidence', Journal of Economic Studies, Vol. 48 No.5, pp.981-995.

Maury, B. (2006) 'Family ownership and firm performance: Empirical evidence from Western European corporations', Journal of Corporate Finance, Vol. 12 No.2, pp.321-341.

McConnell, J.J. and Servaes, H. (1990) 'Additional evidence on equity ownership and corporate value', Journal of Financial Economics, Vol. 27 No.2, pp.595-612.

Mehran, H. (1995) 'Executive compensation structure, ownership, and firm performance', Journal of Financial Economics, Vol. 38 No.2, pp.163-184.

Mitton, T. (2002) 'A cross-firm analysis of the impact of corporate governance on the East Asian financial crisis', Journal of Financial Economics, Vol. 64, pp.215-241.

Morck, R., Shleifer, A. and Vishny, R.W. (1988) 'Management ownership and market valuation: An empirical analysis', Journal of Financial Economics, Vol. 20, pp.293-315.

Nahar A.S. (2004) 'Board composition, CEO duality and performance among Malaysian listed companies', Corporate Governance: The International Journal of Business in Society, Vol. 4 No.4, pp.47-61.

Panyasrivanit, N. (2005) 'Ownership structure, risk and performance of Thai firms: Evidence from Stock Exchange of Thailand (Unpublished doctoral thesis dissertation)', Thammasat University, Bangkok.

Pearce, J.A. and Zahra, S.A. (1992) 'Board composition from a strategic contingency perspective', Journal of Management Studies, Vol. 29 No. 4, pp.411-438.

Rosenstein, J. (1987) 'Why don’t U.S. boards get more involved in strategy?', Long Range Planning, Vol. 20 No.3, pp.30-34.

Sarkar, J. and Sarkar, S. (2000) 'Large shareholder activism in corporate governance in developing countries: Evidence from India', International Review of Finance, Vol. 1, No.3, pp.161-194.

Singh, M. and Davidson, W.N. (2003) 'Agency costs, ownership structure and corporate governance mechanism', Journal of Banking and Finance, Vol. 27 No.5, pp.793-816.

Thomsen, S. and Pedersen, T. (2000) 'Ownership structure and economic performance in the largest European companies', Strategic Management Journal, Vol. 21, pp.689-705.

Uadiale, O.M. (2010) 'The impact of board structure on corporate financial performance in Nigeria', International Journal of Business and Management, Vol. 5 No.10, pp.155-161.

Yermack, D. (1996) 'Higher market valuation of companies with a small board of directors', Journal of Financial Economics, Vol. 40 No. 2, pp.185-211. 